\title{
Positive Feedback Investment Strategies and Destabilizing Rational Speculation
}

\section{Citation}

De Long, J. Bradford, Andrei Shleifer, Lawrence H. Summers, and Robert J. Waldmann. "Positive feedback investment strategies and destabilizing rational speculation." the Journal of Finance 45, no. 2 (1990): 379-395. doi:10.1111/j.1540-6261.1990.tb03695.x

\section{Published Version}

doi:10.1111/j.1540-6261.1990.tb03695.x

\section{Permanent link}

http://nrs.harvard.edu/urn-3:HUL.InstRepos:27693805

\section{Terms of Use}

This article was downloaded from Harvard University's DASH repository, and is made available under the terms and conditions applicable to Other Posted Material, as set forth at http:// nrs.harvard.edu/urn-3:HUL.InstRepos:dash.current.terms-of-use\#LAA

\section{Share Your Story}

The Harvard community has made this article openly available.

Please share how this access benefits you. Submit a story.

\section{Accessibility}


NBER WORKING PAPER SERIES

\title{
POSITIVE FEEDBACK INVESTMENT STRATEGIES AND
} - DESTABILIZING RATIONAL SPECULATION

\author{
J. Bradford De Long \\ Andrei Shleifer \\ Lawrence H. Summers \\ Robert J. Waldmann
}

Working Paper No. 2880

\author{
NATIONAL BUREAU OF ECONOMIC RESEARCH \\ 1050 Massachusetts Avenue \\ Cambridge, MA 02138 \\ March 1989
}

We would like to thank the Russel Sage and Alfred P. Sloan Foundations for financial support, and Robert Barsky, Oliver Hart, Kevin Murphy, Jeremy Stein, and Robert. Vishny for helpful discussions. This paper is part of NBER's research program in Financial Markets and Monetary Economics. Any opinions expressed are those of the authors not those of the National Bureau of Economic Research. 
NBER Working Paper \#2880

March 1989

POSITIVE FEEDBACK INVESTMENT STRATEGIES AND

DESTABILIZING RATIONAL SPECULATION

\section{ABSTRACT}

Analyses of the role of rational speculators in financial markets usually presume that such investors dampen price fluctuations by trading against liquidity or noise traders. This conclusion does not necessarily hold when noise traders follow positive-feedback investment strategies -buy when prices rise and sell when prices fall. In such cases, it may pay rational speculators to try to jump on the bandwagon early and to purchase ahead of noise trader demand. If rational speculators' attempts to jump on the bandwagon early trigger positive-feedback investment strategies, then an increase in the number of forward-looking rational speculators can lead to increased volatility of prices about fundamentals.

\author{
J. Bradford De Long \\ Department of Economics \\ Harvard University \\ Littauer 314 \\ Cambridge, MA 02138 \\ Lawrence H. Summers \\ Department of Economics \\ Harvard University \\ Littauer Center 229 \\ Cambridge, MA 02138
}

Andrei Shleifer Graduate School of Business University of Chicago 1101 E 58th Street Chicago, IL 60637

Robert J. Waldmann Department of Economics Harvard University Littauer Center Cambridge, MA 02138 


\section{INTRODUCTION}

What effect do rational speculators have on asset prices? The standard answer, dating back at least to Friedman (1953), is that rational speculators must stabilize asset prices. Speculators who destabilize asset prices do so by, on average, buying when prices are high and selling when prices are low; such destabilizing speculators would quickly go bankrupt and be eliminated from the market. Speculators who earned positive profits would do so by trading against the less rational or less informed investors who move prices away from fundamentals. To the extent that speculators rationally bet against deviations of prices from fundamentals and so counter them, Friedman concluded that they must stabilize prices.

This argument has been generally accepted in the recent work on noise trading and marke: efficiency (Figlewski, 1979; Kyle, 1985; Campbell and Kyle, 1987; DeLong, Shleifer, Summers, and Waldmann, 1987). In this work, risk aversion keeps rational speculators from taking large arbitrage positions, so noise traders can affect prices. Nonetheless, the effect of rational speculators' trades is to move prices in the direction of even if not all the way to fundamentals. Rational speculators buck noise-driven price movements and so dampen, but do not eliminate them.

In this paper we present what we believe to be an empirically important exception to this argument, based on the prevalence of positive feedback investors in financial markets. Positive feedback investors are those who buy securities when their prices rise and sell when their prices fall. Many forms of behavior common in financial markets can be described as positive feedback trading. It can result from extrapolative expectations about prices, or trend chasing. It can also result from stop-loss orders, which effectively prompt selling in response to price declines. A similar form of positive feedback trading is the liquidation of the positions of investors unable to meet margin calls. Positive feedback trading is also exhibited by buyers of portfolio insurance, who might engage in this practice because their willingness to bear risk decreases rapidly as their wealth declines (Black. 
1988).

In the presence of positive feedback traders, rational speculation can be destabilizing. First, rational speculators bet on the short run future direction of the market if they expect prices to move away from fundamentals. It pays rational speculators to jump on the bandwagon rather than to buck the trend when they do not expect prices to return to fundamentals in the near future. Second, positive feedback traders react to these price moves. For example, when rational speculators buy expecting a future price increase and so raise prices, positive feedback investors react to today's price rise by buying and so raising future prices even further. As a result, prices move further away from fundamentals when rational speculators are present than they would in such speculators' absence. When rational speculation activates the positive feedback strategies of other investors, it can lead to price destabilization.

The mechanics of our model can be simply illustrated. Suppose that rational speculators receive a signal that tomorrow some group of investors without information-some noise traders-will be buying stocks. Because these speculators recognize that this buying will drive the price of stocks to an artificially high level tomorrow, they buy today in anticipation of the price increase. As a result, rational speculators drive the price up-and away from its fundamental value-today. But tomorrow positive feedback traders purchase in response to today's price increase. As a result tomorrow's demand and prices are higher than they would be in the absence of the initial anticipatory purchase by rational speculators, even though rational speculators by then are selling and so bringing prices toward fundamentals. In this model, speculators eventually stabilize prices, but their net effect can be destabilizing if they make positive feedback traders sufficiently aggressive.

This approach to understanding rational speculation has in part been motivated by George Soros' (1987) description of his own investment strategy. Soros has been generally successful over the past two decades by betting not on fundamentals but, he claims, on fu- 
ture crowd behavior. Soros finds clear examples of the trading opportunities he seeks in the 1960's conglomerate and the 1970's Real Estate Investment Trust (REIT) booms. ' In his view, the 1960's saw a number of poorly informed investors become excited about rises in the reported annual earnings of conglomerates. The truly informed investment strategy in this case, says Soros, was not to sell short in anticipation of the eventual collapse of conglomerate shares (for that would not happen until 1970) but instead to buy in anticipation of further buying by uninformed investors. Moreover, the initial price rise in conglomerate stocks, caused in part by purchases of speculators like Soros, stimulated the appetites of uninformed investors since it created a trend of increasing prices and allowed conglomerates to report earnings increases through acquisitions. As uninformed investors bought more, prices rose further. Eventually price increases stopped, conglomerates failed to perform up to uninformed investors' expectations, and stock prices collapsed. Although it is possible that in the end disinvestment and perhaps short sales by smart money brought the prices of conglomerate stocks down to fundamentals, the initial buying by sman money. by raising the expectations of uninformed investors about future returns, may have amplified the total move of prices away from fundamentals. Soros' analysis of REIT's tells the same story.

Soros' self-feeding bubbles are very different from rational bubbles, analyzed recently by Blanchard and Watson (1982) and Tirole (1982). In rational bubbles, the asset earns a positive expected return equal to at least the riskless rate at every point in time. In our model, in contrast, prices are expected to retum to fundamentals at the peak and so the expected retum is then negative. Rational investors go short at the peak. Our model is much more in the spirit of Kindleberger (1978), who sees speculative price movements as involving "insiders [who] destabilize by driving the price up and up, selling out at the top to the outsiders who buy at the top and sell out at the bottom.... [T] he professional insiders initial-

1. For similar accounts, see Tobias (1971), Goodman (1972), and Graham (1974). 
ly destabilize by exaggerating the upswings and the falls, while the outsider amateurs who buy high and sell low are... the victims of euphoria, which infects them late in the day."

Our paper follows a significant literature addressing the question of destabilizing speculation. An early literature responding to Friedman (1953) has stressed that in the presence of rule of thumb investors it might pay a large speculator to destabilize prices (for example Baumol, 1957; Telser, 1959; Kemp, 1963; Farrel, 1966; and Hart, 1977). Although we briefly address the question of price manipulation in section III, our primary interest is in small competitive rational speculators who cannot individually affect prices. Hart and Kreps (1986) constructed a model in which small competitive rational speculators are the only investors able to perform physical storage, and as a result their activity can change commodity supplies in a way that markes equilibrium prices more volatile. It is difficult to compare our framework to that of Hart and Kreps (1986) because in their model price-destabilizing speculation results from the effect of storage on quantities, while in our model quantities are fixed, but equilibrium prices are still less stable in the presence of rational speculators. Stein (1987) observed that imperfectly informed rational speculators introduce noise as well as information into asset prices, and can make prices carry less information about the state of the economy and be less stable. Stein's ingenious idea is perhaps more applicable to dramatic events like the October 1987 market crash, when much uncertainty surrounds the value of fundamentals, than to speculative (but probably not fully rational) bubbles like the conglomerate boom.

This paper is organized as follows. Section I describes some evidence suggesting that positive feedback portfolio strategies are common. Section II presents a simple model that combines speculators' trading in anticipation of noise demand with positive feedback strategies to show that the addition of rational speculators can destabilize prices. Interestingly, the model generates a positive correlation of retums at short horizons, even though at long horizons prices come back to fundamentals and returns, therefore, are nega- 
tively correlated. This feature of realized returns has found some empirical support in recent studies of stock prices (Fama and French, 1988; Poterba and Summers, 1988; Lo and Mackinlay, 1988). The model also predicts that rational speculators can rationally expect an asset to appreciate in the short run and to depreciate over the longer run if the asset has appreciated rapidly in the past. This prediction has been documented for the case of the U.S. dollar in the mid-1980's by Frankel and Froot (1988). Section III of the paper discusses the implications of positive feedback trading for market manipulation by large scale sophisticated investors. Hart (1977) establishes in considerable generality conditions for the profitable operation of an investment pool by a monopolistic speculator when outside investors follow time invariant rules of thumb. The properties of rule of thumb demand that Hart finds sufficient for the possibility of market manipulation are closely related to positive feedback trading. Section IV concludes.

\section{POSITIVE FEEDBACK TRADING}

There are a wide variety of trading strategies that call for buying stocks when their prices rise and selling stocks when their prices fall. These strategies include portfolio choice based on extrapolative expectations, the use of stop-loss orders, purchases on margin which are liquidated when the stock drops below a certain point, as well as dynamic trading strategies such as portfolio insurance. Below we summarize some of the experimental and survey evidence suggesting that positive feedback trading, especially of the extrapolative expectations variety, is common.

The most telling experimental evidence on the tendency of investors to chase the price trend comes from the work of Andreassen and Kraus (1988). ${ }^{2}$ In their experiments, Andreassen and Kraus show subjects with some training in economics authentic stock price

2 In addition, the evidence from market experiments reported in Smith, Suchanek, and Williams (1988) is consistent with trend-chasing by experimental subjects. 
patterns, tell them that these stock prices are authentic, and ask them to trade at given prices. Subjects begin with some endowment and with knowledge of a current stock price, and are then asked to alter their positions with every new observation of the stock price,without having an effect on this price.

Andreassen and Kraus's results are striking. When over some period of observations the level of the stock price does not change very much relative to the period-to-period variability, subjects track this average price level: they sell when prices rise and buy when prices fall. If, however, over a period prices exhibit a trend relative to the period-to-period variability, subjects begin to chase the trend, buying more when prices rise and selling when prices fall. ${ }^{3}$ Instead of extrapolating price levels to arrive at a forecast of future prices, subjects switch to extrapolating price changes. This switch to chasing the trend appears to be a virtually universal phenomenon among the subjects that Andreassen and Kraus study. Interestingly, the switch to trend chasing seems to occur only in response to significant changes in the price level over a substantial number of observations, not in response to the most recent price changes alone.

In addition to experimental evidence, there is a large amount of survey evidence that points to the prevalence of extrapolative expectations. Case and Shiller (1988) find that home buyers in cities where house prices have risen rapidly in the past anticipate much greater future price appreciation than home buyers in cities where prices have been stagnant or have fallen. Shiller (1987) surveys investors in the wake of the 1987 market crash and finds that most sellers in the market cite price declines as the reason that they have sold-presumably because they anticipate further price declines.

Perhaps the most interesting survey evidence on extrapolative expectations is described in Frankel and Froot's (1988) work on the dollar exchange rate in the 1980's. Frankel and

3. Andreassen and Kraus' trending series increased or decreased by nine percent over forty simulated trading days. Their trendless series were adjusted so that the last price quoted in a forty simulated trading day interval was equal to the first price. 
Froot evaluate the forecast and recommendations of a number of exchange rate forecasting services during the period in the mid-1980's when the dollar had been rising for some time without a widening in U.S.-rest of world interest rate differentials and with a rising U.S. trade deficit. Frankel and Froot find that the typical forecaster expected the dollar to continue to appreciate over a period of a month or less simply because it had been appreciating in the recent past, but also expected the dollar to depreciate within a year in accordance with underlying fundamentals. Forecasting services were issuing buy recommendations while maintaining that the dollar was overpriced relative to its fundamental value. Such trend-chasing short-run expectations, combined with a belief in a long-run return to fundamentals, are hard (though not impossible) to reconcile with a fully rational model of pricing the dollar.

Extrapolative expectations are probably the most common form of positive feedback trading, but they are by no means the only form. Although Graham (1974) termed all strategies that call for increased exposure to stocks when prices rise and decreased exposure when prices fall unwise speculation, such strategies can be rational if preferences exhibit risk aversion that declines very rapidly with wealth (Black, 1988). ${ }^{4}$ Nonetheless, it seems more plausible to us to consider the adherence to positive feedback strategies a result of experimentally confirmed biases in judgment akin to those exhibited in Andreassen and Kraus (1988): people tend to find trends where they do not really exist, and to expect these trends to persist. Moreover, as we show below, positive feedback behavior will not result from dynamic hedging strategies by fully rational investors in our model. We therefore assume that positive feedback traders are not rational investors pursuing dynamic hedging strategies but simply noise traders who buy according to a fixed demand curve when prices rise and sell when prices fall.

4. In an analysis similar to Black's attribution of the 1987 crash to portfolio insurance, Irving Fisher (1930) attributed the 1929 crash to stop-loss orders and margined holdings. 


\section{THE MODEL}

\section{Assumptions}

We consider a model in which there are four periods $-0,1,2$, and 3-and two assets, cash and stock. Cash is in perfectly elastic supply and pays no net retum. Stock is in zero net supply. It is liquidated and pays a risky dividend $\theta$ in period 3 , so it should be thought of as side bets that investors make against one another. $\theta$ is distributed nomally with variance $\sigma^{2}{ }_{\theta}$ and mean zero. No meaningful information about $\theta$ is released at any time before period 3, and so the fundamental value of stock until period 3 is always zero.

All investors consume all their wealth in period 3 . The model includes three types of investors: positive feedback traders, present in a measure of one, denoted " $\mathrm{f}$ "; informed rational speculators who maximize utility as a function of period 3 consumption, present in a measure of $\mu$, denoted " $r$ "; and passive price/earnings investors whose demand in all periods depends only on the price relative to its fundamental value of zero, present in a measure of $1-\mu$, and denoted "e." We keep the sum of the shares of the last two types of investors constant to produce comparative statics results on the effect of changes in the number of rational investors while keeping constant the risk-bearing capacity of the economy.

It is easiest to describe the structure of the model and the behavior of investors from period 3 backwards. Table 1 summarizes the assumptions.

\section{Period 3}

In period 3 , there is no trading, and investors pay each other according to the positions they hold in the stock and the announced dividend $\theta$.

\section{Period 2}

In period 2, positive feedback traders receive a demand shock $\bar{v} \in\{-v, 0, v\}$. This demand 


\section{TABLE 1}

\section{STRUCTURE OF THE MODEL}

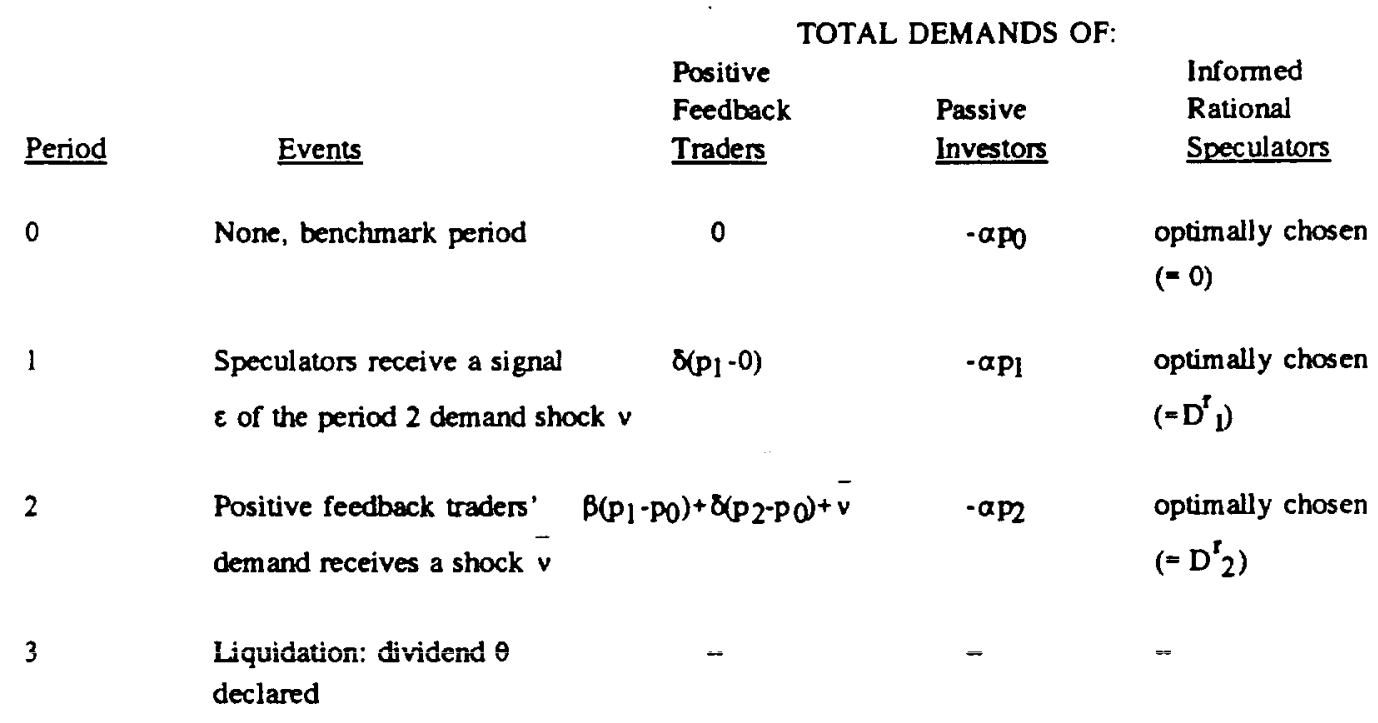

shock is uncorrelated with the period 3 dividend, and represents spurious "news" received by positive feedback traders and their consequent enthusiasm or distaste for stock. We require that $v$ be sufficiently small so as not to upset the mean-variance approximations that will be used in deriving informed speculators' demands. We ascribe this demand shock to positive feedback traders for convenience only: the shock $\bar{v}$ could be any shock that provides a non-zero net demand for stock without carrying information about fundamentals. Both rational and price/eamings investors also leam $v$ in period two (perhaps by uncovering it from prices) and know that $\bar{v}$ has no correlation with the fundamental dividend $\theta$ to be paid in period 3.

Positive feedback traders' demand for stock in period 2 is assumed to be:

$$
D_{2}^{f}=\beta\left(p_{1}-p_{0}\right)+\delta\left(p_{2}-p_{0}\right)+\bar{v}=(\beta+\delta)\left(p_{1}-p_{0}\right)+\delta\left(p_{2}-p_{1}\right)+\bar{v}
$$

where $p_{2}, p_{1}$, and $p_{0}$ are the prices in periods 2,1 , and 0 , and where $\beta$ and $\delta$ are non negative feedback coefficients. In addition to the period 2 demand shock $\bar{v}$, positive 
feedback traders' period 2 demands also respond to price changes with a non-negative coefficient. If the price has risen they buy; if the price has fallen they sell.

Two different positive feedback coefficients are included in the model to allow us to study two different aspects of positive feedback behavior. When $\beta>0$, positive feedback traders react to the past trend in prices. If the price has gone up in the past, they place a market order today. A positive $\beta$ thus reflects Andreassen and Kraus's finding that it takes a sequence of rising prices before their experimental subjects begin to chase the trend. When $\delta>0$, noise traders react to today's price move. This case more closely captures dynamic trading strategies such as portfolio insurance and stop-loss orders.

Since rational investors know that the expected period 3 value of the stock is zero, no rational investor in our model would hold a positive quantity of stocks in period 2 if $\mathrm{p}_{2}>0$. Such a portfolio would be exposed to risk and have a negative expected retum. Our model thus cannot be interpreted as a model of rational portfolio insurance.

Informed rational speculators choose their demand $\mathrm{D}_{2}{ }_{2}$ to maximize a mean-variance utility function with a risk aversion coefficient $\gamma$. In period 2 , the aggressiveness of rational speculators in betting on reversion to fundamentals is limited only by the period 3 fundamental dividend risk, and the demand of a rational speculator is given by:

$$
\text { (2) } D_{2}^{5}=\frac{-p_{2}}{2 \gamma \sigma_{\theta}^{2}}=-\alpha p_{2}
$$

where we substitute an $\alpha$ for the expression $\left(1 / 2 \gamma \sigma_{\theta}{ }^{2}\right)$ for notational convenience.

A passive price-eamings investor's period 2 demand is negatively related to price:

$$
\mathrm{D}_{2}^{\mathrm{e}}=-\propto \mathrm{p}_{2}
$$

where we assume that $\alpha$ is the same as in equation (2). We choose to make the slope of passive investors' demands equal to the period 2 slope of informed rational speculators 
demands, and to have $\mu$ informed rational speculators and $1-\mu$ passive investors, because we would like to examine the consequences of introducing informed rational speculators without changing the risk bearing capacity of the market. Since the slope of passive investors' demand is equal to the slope of rational speculators' demand when the only source of risk is the unknown period 3 fundamental, changes in $\mu$ keep the risk bearing capacity of the economy constant. In the absence of passive investors, an increase in the number of informed rational investors has two opposite effects. It destabilizes prices because it enhances the ability of rational investors' purchases to trigger positive-feedback trading, and it stabilizes prices because it increases the risk-bearing capacity of the market. To focus on the first effect, we introduce passive investors. 5

For the model to have a stable solution when sophisticated investors know the period 2 demand shock with certainty, we require:

(4) $\alpha>\beta+\delta$

When sophisticated investors know the period 2 demand shock with certainty, rational speculation makes period 1 prices rise one-for-one with expected period 2 prices. Unless $\alpha>$ $\beta+\delta$ the model will have no stable equilibrium: for high correctly anticipated values of $p_{2}$ demand will exceed supply. If sophisticated investors are uncertain about the period 2 demand shock, then stable equilibria may still exist as long as their number $\mu$ is nonzero.

\section{Period I}

In period 1 , informed rational speculators receive a signal $\varepsilon \in\{\cdot v, 0, v \mid$ about the period 2 demand shock $\bar{v}$. We consider two different assumptions about the signal $\varepsilon$. First, the signal could be without noise: $\varepsilon=\bar{v}$. Second, the signal could be a noisy signal that satisfies:

5. The model with passive investors is also easier to solve because passive investors are always available for rational investors to trade with. Without passive investors, we need to assume that the risky asset is in positive net supply and to deal with risk premia. 


$$
\begin{aligned}
& \text { (5) } \operatorname{Prob}(\varepsilon=v, \bar{v}=v)=0.25 \quad \operatorname{Prob}(\varepsilon=v, \bar{v}=0)=0.25 \\
& \operatorname{Prob}(\varepsilon=-v, \bar{v}=-v)=0.25 \quad \operatorname{Prob}(\varepsilon=-v, \bar{v}=0)=0.25
\end{aligned}
$$

In the case of a noisy signal, when the speculators' signal $\varepsilon=v$ the expected value of the subsequent demand shock $\bar{v}$ is $v / 2$; when speculators' signal $\varepsilon=\cdot v$, the expected value of the subsequent demand shock $\bar{v}$ is $-v / 2$. In period 1 , informed rational speculators choose their demand $D_{1}^{r}$ to maximize the same mean-variance utility function as in period 2 over the distribution they face as of period 1 of their certain-equivalent wealth in period 2.6

Passive investors' demand in period 1 takes the same form as in period 2. They buy low and sell high, and their demand is given by:

(6) $\quad D_{1}^{e}=-\alpha p_{1}$

Positive feedback traders' demand in period 1 takes the form:

$$
\text { (7) } \quad D_{1}^{f}=\delta p_{1}
$$

They receive no demand shock. If they react immediately and automatically to changes in market prices (that is, if $\delta>0$ ), they buy if the market rises in period 1 and sell if it falls. If their positive feedback behavior takes the form of reacting to the past trend of price movements $(\beta>0)$ but not to current price changes $(\delta=0)$, then positive feedback traders do not trade in period 1.

\section{Period 0}

Period 0 is a reference period. No signals are received. As a result, the price is set at its initial fundamental value of zero, and there is no trading. Period 0 provides a benchmark against which the positive feedback traders can measure the appreciation or depreciation of

6. Preferences are thus time consistent up to the approximation error of the mean-variance formulation. 
stock from period 0 to periods 1 and 2 , and so form their positive feedback demands in periods 1 and 2 .

Since there is no trading in periods 0 or 3 , the market clearing conditions are automatically satisfied in those periods. For periods 1 and 2 , since there are $\mu$ informed rational speculators and $1-\mu$ passive investors the market clearing conditions are:

(8) $\quad 0=D_{1}^{f}+\mu D_{1}^{r}+(1-\mu) D_{1}^{f}$

(9) $\quad 0=D_{2}^{f}+\mu D_{2}^{r}+(1-\mu) D_{2}^{e}$

\section{Solution with a Noiseless Signal}

We consider the case of a positive demand shock, $\bar{v}=+v$. The argument is symmetric in the case of a negative demand shock. If rational speculators' signal $\varepsilon$ is perfectly correlated with the period 2 demand shock $\bar{v}$, then from rational speculators' point of view there is no uncertainty in period 1 about positive feedback traders' demand or the asset price in period 2. As long as informed rational speculators are present in positive measure $(\mu>0)$, arbitrage guarantees the equality of prices in periods 1 and 2 . If there are no informed rational speculators present $(\mu=0)$, then the period 1 price equals zero:

$$
\begin{array}{ll}
\text { (10) } \mathrm{p}_{1}=\mathrm{p}_{2} & \text { if } \mu>0 \\
\mathrm{p}_{1}=0 & \text { if } \mu=0
\end{array}
$$

Imposing market clearing in period 2, and substituting in the period 2 demands (1), (2), and (3), yields the period 2 equilibrium condition:

$$
\text { (11) } 0=\delta p_{2}+\beta p_{1}+v-\alpha p_{2}
$$

Combining (10) and (11), we obtain: 
(12)

$$
\begin{array}{ll}
p_{1}=p_{2}=\frac{v}{\alpha-(\delta+\beta)} & \text { if } \mu>0 \\
p_{1}=0 \quad p_{2}=\frac{v}{\alpha-\delta} & \text { if } \mu=0
\end{array}
$$

If $\beta>0$, then the price is strirtly further away from fundamentals if rational informed speculators are present than if they are absent. If $\beta=0$ but $\delta>0$, then prices are strictly further away from fundamentals in period 1 , but only as far away from fundamentals in period 2 . In the case of a noiseless signal, therefore, the addition of informed rational speculators pushes prices away from fundamentals in at least some periods without bringing them closer to fundamentals in other periods.

The path of prices in the case of a noiseless signal is discontinuous: $\mu=0$ and $\mu \ll 1$ are not nearly equivalent. Moreover, once $\mu \neq 0$ the path of prices is invariant to changes in $i$. These peculiarities arise from the fact that the signal is noiseless. For an informed rational speculator, the round-trip trade that involves a purchase in period 1 and a sale in period 2 carries no risk because noise traders' period 2 demand is perfectly predictable and fundamental risk does not appear until period 3. Even a very small measure $\mu$ of informed rational speculators will consequently be willing to undertake an arbitrarily large amount of arbitrage trades. To make holding stocks between periods 1 and 2 risky, we next consider the case in which rational speculators' signal $\varepsilon$ of noise traders' demand shock $\bar{v}$ is imperfect.

\section{Solution with an Imperfect Signal}

Suppose that rational speculators receive a noisy signal, as in equation (5). Once again we consider the case of a positive demand shock experienced by period 2 positive feedback traders. Because the symmetric solution obtains when $\varepsilon=-v$, we do not discuss that case 
FIGURE 1

NOISELESS SIGNAL: PRICES WITH AND WITHOUT INFORMED SPECULATORS $v=0.25, \alpha=0.5, \beta=0.2, \delta=0.2$

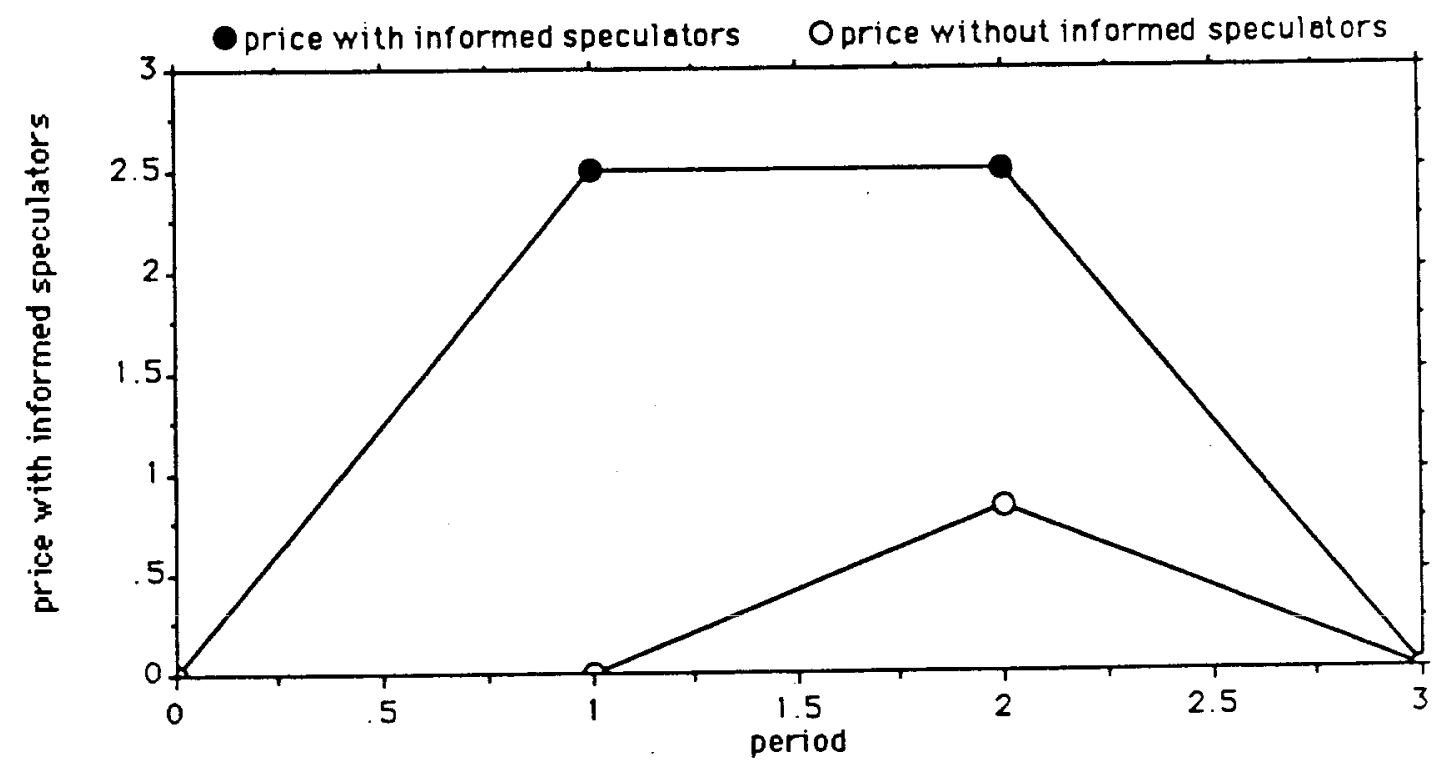

here. Conditional on $\varepsilon=v$, there are two states of the world in period 2 , which will be denoted $2 a$ and $2 b$. In state $2 a, \bar{v}=+v$ and positive feedback traders are indeed bullish; in state $2 b, \bar{v}=0$ and positive feedback traders' demand is not shocked.

There are now two market clearing conditions for period 2, which together replace equation (11) for states $2 a$ and $2 b$ respectively:

$$
\begin{aligned}
& \text { (14a) } 0=\delta p_{2 a}+\beta p_{1}+v-\alpha p_{2 a} \\
& \text { (14b) } 0=\delta p_{2 b}+\beta p_{1}-\alpha p_{2 b}
\end{aligned}
$$

The market clearing condition for period 1 is simply that:

$$
0=(\delta \cdot(\alpha(1-\mu))) p_{1}+\mu D_{1}{ }^{r}
$$

with informed rational investors' period 1 demand $D^{r}{ }_{1}$ still to be determined. The 
investment opportunities open to informed rational speculators are such as to give them, along with their purchases $D^{r}{ }_{1}$ in period 1 for sale in period 2 , certain-equivalent wealth as of period 2 in the two states $a$ and $b$ of:

$$
\begin{aligned}
& \text { (16a) } W_{2 a}=\left(p_{2 a}-p_{1}\right) D_{1}^{r}+\frac{\alpha\left(p_{2 a}\right)^{2}}{2} \\
& \text { (16b) } W_{2 b}=\left(p_{2 b}-p_{1}\right) D_{1}^{r}+\frac{\alpha\left(p_{2 b}\right)^{2}}{2}
\end{aligned}
$$

Since an investor is indifferent between his actual opportunity set as of period 2 and his period 2 certain-equivalent wealth, we can replace the investors' period 2 problem with its associated certain-equivalent wealth without altering any of his period 1 choices. Choosing $\mathrm{D}^{\mathrm{r}}{ }_{1}$ to maximize mean-variance expected utility as of period 1 then yields speculators period 1 demand:

$$
\text { (17) }\left\{\frac{\frac{p_{2 a}+p_{2 b}}{2}-p_{1}}{2 \gamma\left(\left(p_{2 a}-p_{2 b}{ }^{2}\right)^{2}\right)}\right\}-\alpha\left(\frac{p_{2 a}+p_{2 b}}{2}\right)=D_{1}^{r}
$$

Recall that rational speculators' period 2 demands are simply expected retums divided by the next period's risk; they are proportional to the expected return -p2 and inversely proportional to the fundamental risk $\sigma_{\theta}{ }^{2}$ run in holding stocks from period 2 to period 3 . Period 1 demands are more complex. They do not have a simple risk/retum interpretation. There is an additional term that arises because rational investors do not have to buy in period 1 if they wish to sell in period 2 . If the period 2 price of stock is high, rational speculators can make money by simply selling short in period 2 and covering in period 3 . The ability of rational speculators to go short and cover in period 3 provides them with partial insurance against a failure to purchase in period 1 and so missing the initial price rise. Consequently, an informed speculator's period 1 demand is smaller than it would be if he 
were myopic and just looked one period ahead.

Equations (14a), (14b), (15), and (17) form a system in four unknowns, the three prices $\mathrm{p}_{1}, \mathrm{p}_{2 \mathrm{a}}$, and $\mathrm{p}_{2 \mathrm{~b}}$, and informed speculators' period 1 demand $\mathrm{D}_{1}^{r_{1}}$. Solving this system for the period 1 price yields:

$$
p_{1}=\frac{\frac{\alpha-\delta}{w} \cdot \frac{\alpha v}{2(\alpha-\delta)}}{\frac{\alpha-\delta}{\mu}+(\alpha-(\beta+\delta))\left\{\frac{2(\alpha-\delta)}{w^{2}}-\frac{\alpha}{\alpha-\delta}\right\}}
$$

if $\mu>0$, and:

(19) $\mathrm{p}_{1}=0$

if $\mu=0$.

Note that (18) and (19) are continuous at $\mu=0$. As $\mu \rightarrow 0$, the first term in the denominator of (18) becomes very large and so $p_{1} \rightarrow 0$ as well. As long as $\alpha>\beta+\delta$ and the magnitude $v$ of the demand shock is small enough to keep the numerator of (18) positive, the entire expression (18) will be positive. The requirement that $\alpha>\beta+\delta$ was imposed above to ensure that the model with a noiseless signal had a stable solution; the requirement that the magnitude $v$ of the demand shock be small is necessary for the mean-variance approximation used to compute informed rational speculators' period 1 demands to hold.

Now consider the derivative of (18) with respect to the number $\mu$ of rational speculators. Since $\mu$ appears only in the first term in the denominator, the period 1 price is increasing in the number $\mu$ of rational speculators as long as $p_{1}>0$ and $\alpha>\delta$.

Rewriting (14a) and (14b) reveals that: 


$$
\begin{aligned}
& \text { (20a) } p_{2 a}=\frac{\beta p_{1}+v}{\alpha-\delta} \\
& \text { (20b) } p_{2 b}=\frac{\beta p_{1}}{\alpha-\delta}
\end{aligned}
$$

As long as $\beta>0$, the period 2 prices in the two states of the world are themselves strictly increasing in the period 1 price. If $\beta=0$, however, the period 2 prices are invariant to the period 1 price. If positive feedback traders' demands does not react to past trends-if $\beta=0$-then, holding constant the risk bearing capacity of the economy, an increase in the number $\mu$ of rational speculators weakly destabilizes prices: it pushes them further away from fundamentai vaiues in periou 1 , tuit has no effect on prices in period 2. By contrast, if positive feeback traders' demands do react to past trends-if $\beta>0$-then in this model an increase in the number $\mu$ of informed rational speculators strongly destabilizes prices: it pushes them further away from fundamental values at all times and in all states of the world.

The effect of speculation on the pattern of prices for one set of sample parameter values is shown in figure 2. Because speculators bet on $v$ being high in period 2, they drive the period 1 price up above zero; this in tum raises positive feedback trader demand in period 2 in both states of the world. Speculators buy in period 1 when they receive a positive signal even though they have a long horizon and recognize that the fundamental value of the asset is still zero. This betting on future positive feedback trader demands drives the price in period 1 above its fundamental value of zero.

However, the period 1 price still reflects uncertainty about positive feedback traders' period 2 demand. As long as rational investors respond to news that there will be a positive shock to demand in the future by buying stock in period 1, risk aversion implies that the 
FIGURE 2

SAMPLE PRICE PATTERNS WITH A NOISY SIGNAL

$$
\begin{aligned}
\alpha=1, \delta=0.2, \beta & =0.2, \gamma=1, \varepsilon=.25 \\
v & =.25
\end{aligned}
$$
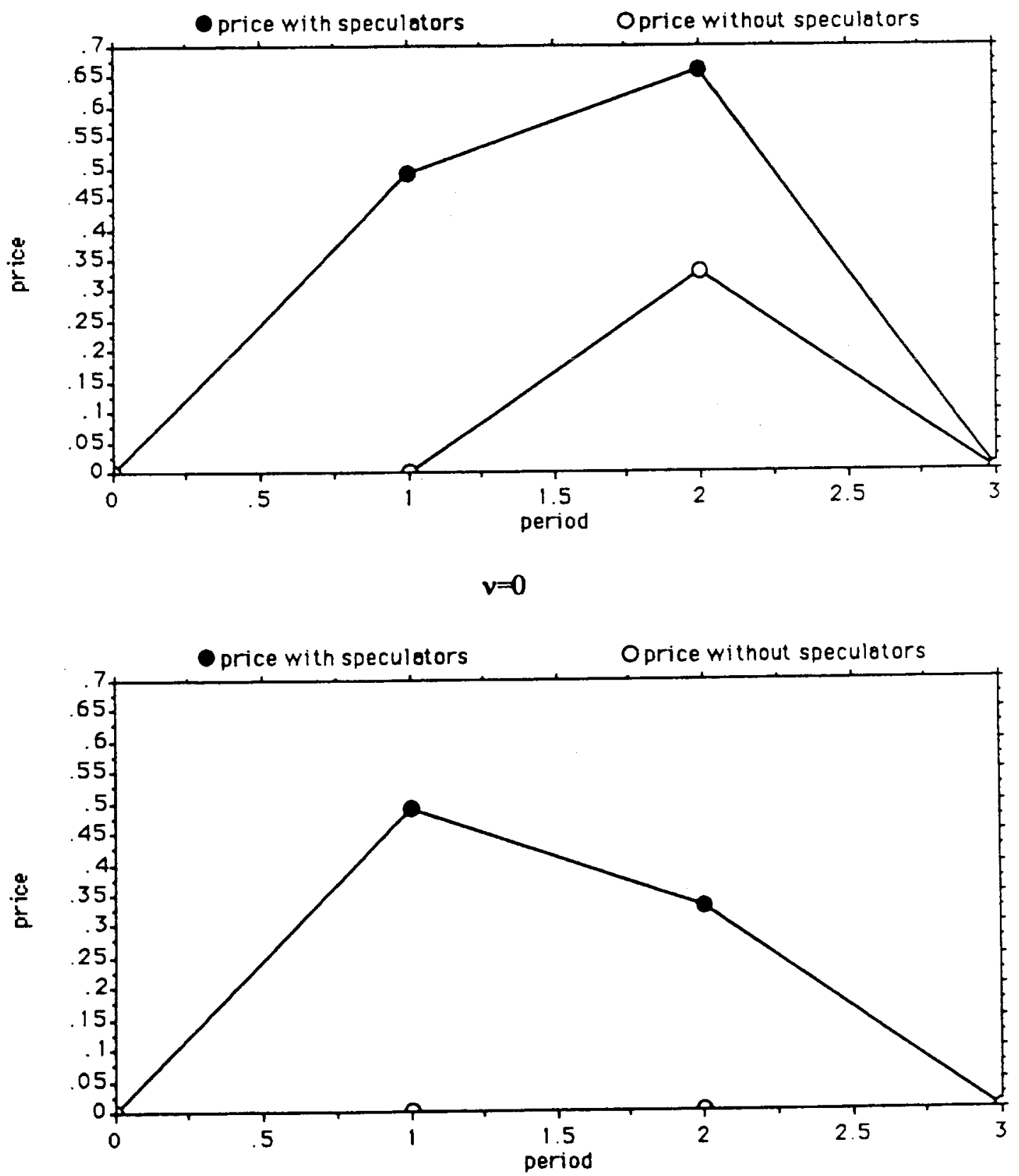
period 1 price will be closer to fundamentals than the average period 2 price. Short-run price movements from period 0 to period 1 will on average continue from period 1 to period 2: retums will therefore be positively correlated at short horizons, even though at long horizons-in period 3 in this model-prices come back to fundamental values and two period returns are negatively correlated.

This pattem of correlations is consistent with recent empirical work that has documented a similar sign pattern-positive serial correlation of price changes at shor horizons coupled with eventual mean reversion in the long run-in asset prices (see Fama and French, 1988; Poterba and Summers, 1988; and Lo and Mackinlay, 1988). We stress that our paper has little to say about what is a short and what is a long horizon. In particular, we assume that period 3 is the end and so prices must then retum to fundamentals. According to the evidence, the "short horizon" is between a week and a few months, and the "long horizon" is perhaps four years. A more complete theory than ours would have something to say about these horizons.

Interestingly, Frankel and Froot (1988) find that market participants expect recent price changes to trigger others in the same direction, while they also expect prices to return to fundamental values in the longer run. Such a pattem of expectations is analogous to that held by the fully rational optimizing speculators in our model. Frankel and Froot present a model in which some investors, termed "chartists," hold short-run extrapolative expectations, while other investors, called "fundamentalists," believe in long-run mean reversion. The interaction of the two types of investors generates the price patterns they find empirically.

The important point that our model illustrates is that the same rational investors can expect price trends to continue in the short run and to revert toward the mean in the long run. A belief that in the short run prices will move in a different direction than in the long run does not mean that one's expectations are inconsistent. Such expectations may indicate only 
that positive feedback traders, trading in response to price movements that may well have been largely generated by anticipations of their own purchases, are important for the short-run price behavior of an asset market that in the long run tends to revert to fundamentals. Positive serial correlation at short horizons and negative serial correlation at longer horizons arise from the combination of speculators' anticipatory trades and positive feedback trading strategies.

The combination of positive retum correlations at short horizons and eventual reversion to the mean corresponds to a conventional view of a price bubble. Our version of such a bubble relies on the positive feedback investment strategies of a significant number of investors, aggravated by arbitrageurs' anticipatory pumping up of the bubble. As we men. tioned in the introduction, this description of price bubbles is not new. For example, Goodman (1968) refers to an "informal theorem of chartism" that classifies phases of price movements in terms of categories-accumulation, distribution, and liquidation-that correspond one-to-one to the periods of our model. Accumulation involves purchases by informed investors in anticipation of a future price rise, and reveals itself through increased volume and upward price pressure; distribution involves "the smart people who bought it early selling to the dumb people who bought it late"; and liquidation involves the return of prices to fundamental values.

A key difference between the positive-feedback bubbles present in our model and rational bubbles (for example, Tirole, 1982) is that in our model the expected retum on stocks turns negative at the peak. Informed rational investors and passive price-eamings investors both correctly know in period 2 that future expected retums are negative; the presence of uninformed positive feedback traders sustains the high period 2 price. Moreover, technical analysis might prove profitable in our model if it could provide some way of distinguishing between purchases made in advance of the release of good fundamental news and purchases made in advance of shifts in noise demand. 


\section{MARKET MANIPULATION}

So far we have assumed that rational speculators are competitive, but have some information about the future moves of positive feedback investors. A separate, but closely related, issue is the possibility of market manipulation by rational speculators with no valid information about the future in the presence of positive feedback traders. Initial purchases by a group of speculators may, even in the absence of information either about fundamentals or about exogenous future noise demands, trigger sufficient purchases by positive feedback investors to allow the group of speculators to make a profit.

An illustration of this phenomenon is the "pool" in RCA stock purportedly operated by Michael Meehan between March 7 and March 22, 1929.7 On March 7, Meehan purportedly issued a "private and confidential" invitation to participate in a short-term trading syndicate in RCA stock which was accepted by 68 investors who together subscribed $\$ 12,000,000$. On Monday March 11, "The Trader" in the New York Daily News announced that RCA should rise to $\$ 100$ soon and that "Tuesday it should be a real buy"; RCA closed at $\$ 901 / 8$. On Tuesday the pool allegedly began its own operations and RCA closed at $\$ 915 / 8$. On Wednesday the Wall Street Journal reported that RCA had advanced "to fresh record levels, on the activities of the big operators who have sponsored Radio's market for the last several weeks," and RCA closed at \$94. On Saturday RCA closed at \$109 1/4.

The following week the pool sold off its net long position, reportedly of 239,000 shares. at prices between $\$ 109$ and $\$ 92$ 1/2. Friday March 22 saw the Wall Street Journal report that "the large pool in Radio finished letting out its line Tuesday and, for the time being at least, has tumed its attention to... Anaconda." RCA closed at $\$ 87$ 1/4 on Saturday March

7. Cowring (1965), Brooks (1969), Wigmore (1987). 
23.

Total gross sales and purchases by the pool allegedly amounted to 1,500,000 RCA shares. The net rate of return on invested capital was allegedly at least $12 \%$ over two week (Wigmore, 1987). But such operations, even by experienced Wall Street professionals, were not riskless. Before the pre-WWI Pujo committee investigating the "Money Trust," broker Harry Content argued that such market manipulations would not take place in the future. because no Wall Street operator would participate in a pool for fear of being double-crossed by pool insiders.

The possibility of such profitable "pool" operations is remote without a large positive feedback element in market demand. In fact, Kyle (1985) has shown that it does not pay a monopolist to destabilize prices if noise trader demands are independent and identically distributed. Hart (1977) has studied in considerable generality the conditions under which a rational monopolistic speculator facing a group of investors operating according to rules-ofthumb can profitably manipulate the market. If rule-of-thumb demand is an invariant linear function of past prices, then a sufficient condition for profitable market manipulation is that the difference equation describing the evolution of prices in the absence of trading by the monopolist is explosive. Moreover, this is a sufficient and not a necessary condition: there are some processes for noise trader demand that fail to lead to explosive prices and yet allow for profitable market manipulation.

Our model is explosive if:

$$
\text { (21) } \quad \alpha<\beta+\delta
$$

Equation (21) is the reverse of equation (4), assumed to hold throughout this paper in order to guarantee stability. If (21) holds, an atom of rational speculators can buy in period 1, sell in period 2, and eam positive profits with no risk. The positive-feedback demand provoked by the initial period 1 purchase is so large that the atom of speculators can liquidate their 
position at a higher price in period 2.8 If $(21)$ holds, positive-feedback traders so dominate the market that it is in the interest of an atom of speculators to buy in period 1 even if they have no information either about fundamentals or about future noise demands. Moreover, (21) is a sufficient and not a necessary condition for a monopolistic atom of speculators to be able to manipulate the market and make money.

Equation (21) is a necessary condition for a pool to be self-enforcing. An outsider who learns of the pool in period 1 will then find it profitable to join the pool, not to speculate against it. If (21) did not hold, then an informed rational speculator outside the pool could make money by selling to the pool in period 1, selling to positive feedback traders in period 2 , and covering his position in period 3. Such traders would dampen the ability of the pool's initial period 1 purchase to stir up the market.

\section{CONCLUSION}

Theoretical arguments for the efficiency of financial markets rely crucially on the stabilizing powers of rational speculation. These arguments say essintially that rational speculators will "buck the trend" and by doing so bring prices closer to fundamental values. Previous research has questioned the effectiveness of such speculation in the presence of risk aversion. Figlewski (1979) stressed fundamental risk as a deterrent to rational speculation, and DeLong, Shleifer, Summers, and Waldmann (1987) noted that the unpredictability of irrational behavior can itself be the source of risk that renders rational speculation less effective. Both of these papers, however, subscribed to the basic idea that

8. The quantity of stocks that such an atom of speculators will wish to buy in period 1 is unbounded: such a pool earns expected profits proportional to the scale on which it is mounted and carries no risk. If our model were complicated by the addition of fundamental risk in period 2 , the tradeoff between risk and retum would imply the existence of an optimal size for a pool. Problems connected with the tendency of additional speculators to free-ride on the pool's profits would then arise. 
rational speculators counter the irrational movements in asset prices.

This paper has argued, to the contrary, that in the presence of positive feedback investors it might be rational for speculators to jump on the bandwagon and not to buck the trend. Rational speculators who expect some future buying by noise traders would buy today in the hope of selling at a higher price tomorrow. Moreover, purchases by rational speculators can make positive feedback traders even more excited and so move prices even further away from fundamental values than they would go in the absence of rational speculators. Unlike previous papers, which have argued that the magnitude of the stabilizing arbitrage positions taken by rational speculators might be small, this paper claims that the sign of arbitrage positions can be the opposite of what one needs to move markets toward stability and efficiency.

There are many examples of such destabilizing speculation, some of which have already been noted. George Soros' riding of the conglomerate and REIT speculative waves is one example, and he is by no means the only investor who attempts to practice such trading in anticipation of irrational demand (Keynes, 1936). John Train (1987), in his book of profiles of successful U.S. investors, refers to the activity of one of his protagonists as "pumping up the tulips." Other, perhaps more common examples of destabilizing rational speculation include frontrunning by investment banks. Investment banks and brokers familiar with the customer order flow have perhaps the best of all information about future levels of demand. Investment pools explicitly designed to activate positive feedback investors may be yet another example of the phenomena outlined in our model.

Moreover, our model accounts for some of the observed statistical regularities in asset price behavior. It rationalizes the observed positive correlation of retums at short horizons combined with a negative correlation of long horizon retums. The model also illustrates how investors can rationally expect an asset to move in one direction in the short run and in the opposite direction in the long run. In future work, we hope to present additional 
empirical evidence bearing on the question of the importance of positive feedback trading in financial markets. 


\section{REFERENCES}

Andreassen, Paul and Stephen Kraus (1988), "Judgmental Prediction by Extrapolation," Harvard University mimeo.

Blanchard, Olivier and Mark Watson (1982), "Bubbles, Rational Expectations, and Financial Markets," in Paul Wachtel, ed., Crises in the Economic and Financial Structure (Lexington, MA: D.C. Heath), 295-316.

Baumol, William J. (1957), "Speculation, Profitability, and Stability," Review of Economics and Statistics 35: 263-71.

Black, Fischer (1988), “An Equilibrium Model of the Crash," NBER Macroeconomics Annual 1988: 269-76.

Campbell, John Y. and Albert S. Kyle (1988), "Smart Money, Noise Trading, and Stock Price Behavior," NBER Technical Working Paper \#72.

Case, Karl and Robert Shiller (1988), "The Behavior of Home Buyers in Boom and Post Boom Markets," NBER Working Paper \#2748.

Cowing, Cedrick (1965), Populists, Plungers, and Progressives: A Social History of Stock and Commodity Speculation 1890-1936 (Princeton: Princeton University Press).

De Long, J. Bradford, Andrei Shleifer, Lawrence H. Summers, and Robert J. Waldmann (1987), "Noise Trader Risk in Financial Markets," NBER Working Paper \#2385.

Fama, Eugence F. and Kenneth R. French (1988), "Permanent and Temporary Components of Stock Prices," Journal of Political Economy 96 (April): 246-73.

Farrell, Michael J. (1966), "Profitable Speculation," Economica 33: 183-93.

Frankel, Jeffrey and Kenneth Froot (1988), “Explaining the Demand for Dollars: Intemational Rates of Return and the Expectations of Chartists and Fundamentalists," in R. Chambers and P. Paarlberg, eds., Agriculture, Macroeconmics, and the Exchange Rate.

Friedman, Milton (1953), "The Case for Flexible Exchange Rates," in Essays in Positive Economics (Chicago: University of Chicago Press).

Goodman, George ["Adam Smith”] (1968), The Money Game (New York: McGraw-Hill).

Goodman, George [“Adam Smith”] (1972), Supermoney (New York: McGraw-Hill).

Graham, Benjamin and David L. Dodd (1934), Sciürity Analysis (New York: McGraw Hill); also 3d ed. 1951.

Greenwald, Bruce and Jeremy Stein (1988), “The Task Force Report: The Reasoning 
Behind the Recommendations," Journal of Economic Perspectives 2, 3 (Summer): 3-24.

Hart, Oliver (1977), "On the Profitability of Speculation," Quarterly Journal of Economics 101: 579-97.

Hart, Oliver and David Kreps (1986), "Price Destabilizing Speculation," Journal of Political Economy 94 (October): 927-52.

Kemp, Michacl (1963), "Speculation, Profitability, and Price Stability," Review of Economics and Statistics 45 (May): 185-9.

Keynes, John Maynard (1936), The General Theory of Employment, Interest, and Money (London: Macmillan).

Kindleberger, Charles P. (1978), Manias, Panics, and Crashes (New York: Basic Books).

Kyle, Albert S. (1985), “Continuous Auctions and Insider Trading," Econometrica 47: 1315-36.

Leland, Hayne and Mark Rubinstein (1988), "Comments on the Market Crash: Six Months After," Journal of Economic Perspectives 2, 3 (Summer): 45-50.

Lo, Andrew and Craig MacKinlay (1988), "Stock Prices Do Not Follow Random Walks: Evidence from a Simple Specification Test," NBER Working Paper \#2168.

Poterba, James M. and Lawrence H. Summers (1988), "Mean Reversion in Stock Retums: Evidence and Implications," Journal of Financial Economics 22 (February): 27-59.

Shiller, Robert (1988), "Portfolio Insurance and Other Investor Fashions as Factors in the 1987 Stock Market Crash," NBER Macroeconomics Annual 1988: 287-96.

Smith, Vemon, Gerry Suchanek, and Arlington Williams (1988), "Bubbles, Crashes, and Endogenous Expectations in Experimental Stock Markets," Econometrica 56: 1119-51.

Soros, George (1987), The Alchemy of Finance (New York: Simon and Schuster).

Stein, Jeremy (1987), "Informational Externalities and Welfare-Reducing Speculation," Journal of Political Economy 95 (December): 1123-45.

Telser, L.G. (1959), "A Theory of Speculation Relating Profitability and Stability," Review of Economics and Statistics 37 (August): 295-301.

Thomas, Gordon and Max Morgan-Witts (1979), The Day the Bubble Burst (New York Penguin).

Tirole, Jean (1982), “On the Possibility of Speculation Under Rational Expectations," Econometrica 50: 1163-81.

Tobias, Andrew (1971), The Funny Money Game (Chicago: Playboy Press).

Train, John (1979), "Pumping Up the Tulips," Forbes (October 1). Reprinted and expanded 
in The Money Masters (New York: Harper and Row, 1987).

Wigmore, Barrie (1985), The Crash and Its Aftermath (Westport, CN: Greenwood Press). 